\title{
PROPRIEDADE INTELECTUAL - A VIDA E O CONHECIMENTO A SERVIÇO DO MERCADO
}

Anderson Marcos dos Santos*

RESUMO: A propriedade intelectual foi construída na modernidade como direito subjetivo para proteger o autor e propiciar o desenvolvimento econômico, tecnológico, social e cultural dos povos. Da mesma forma, a tecnociência apresenta-se como elemento propulsor de um novo tempo, que promete vida longa e mais saudável. Porém, a associação entre a lógica de mercado e uma racionalidade puramente instrumental da biotecnologia podem levar o Direito, por meio do sistema internacional de patentes, estabelecido pelo Acordo Trips, a transformar-se, de protetor, em instrumento de colonização dos saberes e de reificação do humano.

\section{TECNOCIÊNCIA, MERCADO E DIREITO}

A fusão da racionalidade tecnocientífica e econômica, ocorrida nas últimas três décadas, alterou os parâmetros de investimentos do capital, que deixou de ter por base o seu retorno e passou a investir na dinâmica de permanentes inovações. Esse fenômeno ocasionou uma corrida tecnológica que penetrou tanto na vida, com a biotecnologia, como no mercado, por meio do biomercado,

\footnotetext{
* Mestre em relações sociais pela UFPR, professor de Direito Civil na UNICENP, pesquisador do Núcleo de Direitos Humanos da UFPR - linha de pesquisa: direito, sociedade e biotecnologia.
}

transformando a vida em mercadoria e o mercado em uma apropriação antecipada do futuro. ${ }^{1}$ Além disso, devido ao potencial de valorização e da acelerada substituição dos materiais, essa fusão tornou-se rapidamente em um dos principais instrumentos de reprodução do capital e, por isso mesmo, um dos mais fortes centros de decisões políticas e jurídicas na sociedade globalizada. Contexto este, importante para compreender a regulação jurídica sobre a tecnociência.

\footnotetext{
1 SANTOS, L. G. dos. Politizar as novas tecnologias: o Impacto sócio-técnico da informação digital e genética. São Paulo: Editora 34, 2003. p.232.
} 
Esse processo iniciou-se a partir dos anos 70 , quando a riqueza de bens tangíveis perde sua prevalência na economia mundial. $\mathrm{Na}$ nova ordem econômica, não são mais os minerais que conferem vantagem comercial, agora, a tecnociência transforma as informações genéticas em fator primordial de produção. O mercado volta-se para a apropriação da natureza não mais como bem corpóreo apropriável, mas como bem intangível. As plantas, os animais, inclusive o homem, valem, agora, pelo potencial de inovação que seus elementos genéticos podem carregar. A informação ${ }^{2}$ passa a ser a matéria-prima que garante a vantagem concorrencial no mercado.

$\mathrm{O}$ principal instrumento jurídico utilizado para a apreensão desses bens, de tal forma eficaz que permita a maximização dos lucros por seus detentores, passa a ser a propriedade intelectual, mais especificamente a concessão de patentes de invenção, que permite a apropriação individual e privada daquilo que é natural e coletivo.

A propriedade intelectual, hoje regulada em âmbito internacional pelo Acordo sobre Aspectos da Propriedade Intelectual

2 "A informação torna-se crucial a partir do momento em que a dimensão virtual da realidade começa a ser mais importante do ponto de vista econômico e tecnocientífico do que a sua dimensão atual. A lógica que preside a conduta da tecnociência e do capital com relação aos seres vivos, agora transformados em recursos genéticos, é a mesma que se explicita em toda parte: trata-se de privilegiar o virtual, e de preparar o futuro para que ele já chegue apropriado, trata-se de um saque no futuro e do futuro". SANTOS, L. G. dos. Informação, Recursos Genéticos e Conhecimento Tradicional Associado. In: AZEVEDO, C. M. do A.; FURRIELA, F. N. da (Orgs.). Biodiversidade e Propriedade Intelectual. São Paulo: SMA, 2001. p.37.
Relacionados ao Comércio (ADPIC/TRIPS), funciona no regime jurídico da propriedade em geral, ou seja, garante a um titular o direito individual e exclusivo de utilização do bem. No entanto, as condições são mais perversas, uma vez que na propriedade de coisas corpóreas o proprietário apropria-se de um bem material, tangível, único. Na propriedade intelectual, o proprietário apropria-se daquilo que é coletivo, essencialmente coletivo, que é o conhecimento e a vida, não mais do indivíduo, mas da espécie.

Para que esse instrumento sirva adequadamente aos interesses do mercado, no caso das patentes, é necessária uma flexibilização no entendimento de seus dos próprios fundamentos jurídicos e das categorias, legais $^{3}$ e doutrinárias, que justificaram a criação da propriedade intelectual como um direito subjetivo.

Assim, os fundamentos da propriedade industrial: o direito do autor, o desenvolvimento tecnológico e o controle da concorrência desleal são abalados pela própria lógica imprimida pelo mercado.

Com efeito, o reconhecimento do autor deixou de existir a partir do momento em que as inovações estão atreladas a uma grande quantidade de capital, o que impossibilita a existência de um inventor isolado e faz as inovações ocorrem por meio de uma atividade empresarial em que o trabalho é dividido e resulta do esforço de muitas pessoas submetidas a contratos de trabalhos cujo

3 No Brasil a lei que disciplina a propriedade industrial é a n. ${ }^{\circ} 9.279 / 96$, feita conforme as determinações do Acordo Trips. 
retorno, de regra, fica para o investidor, essa é a determinação do art. 88 da lei n. ${ }^{\circ} 9.279 / 96 .^{4}$

Por sua vez, o desenvolvimento tecnológico e os resultados sociais que dele se esperam são limitados pela possibilidade ou não dos destinatários de serem consumidores. Pois, mesmo havendo a publicização da invenção, essa é uma propriedade exclusiva e como tal só é acessível mediante remuneração ao detentor da patente.

Em relação à concorrência desleal, surge um paradoxo: o principal fundamento da propriedade industrial é evitar que aquele que destinou tempo e dinheiro para a produção de uma invenção não seja prejudicado por outrem que, por um atalho, utilize-se desta invenção sem uma devida retribuição para o detentor da patente. Entretanto, tem-se permitido o patenteamento de seqüências genéticas, sem a produção de qualquer produto. Assim, patentea-se uma "área" do futuro, impondo para novas invenções que possam decorrer da seqüência patenteada o dever de remunerar aquela primeira. Procedimento absolutamente oposto à idéia de lealdade na concorrência.

4 A Lei n. ${ }^{\circ}$ 9.279/96 dispõe a respeito das invenções feitas durante a vigência de contrato de trabalho:

Art. 88. A invenção e o modelo de utilidade pertencem exclusivamente ao empregador quando decorrerem de contrato de trabalho cuja execução ocorra no Brasil e que tenha por objeto a pesquisa ou a atividade inventiva, ou resulte esta da natureza dos serviços para os quais foi o empregado contratado.

$\$ 1^{\circ}$ Salvo expressa disposição contratual em contrário, a retribuição pelo trabalho a que se refere este artigo limita-se ao salário ajustado.

$\S 2^{\circ}$ Salvo prova em contrário, consideram-se desenvolvidos na vigência do contrato a invenção ou o modelo de utilidade, cuja patente seja requerida pelo empregado até 1 (um) ano após a extinção do vínculo empregatício.
Quanto às categorias jurídicas, há uma deliberada nebulosidade entre o conceito de invenção, requisito legal para a concessão da patente, e o de descoberta, com o fim de permitir o patenteamento de informações genéticas. Com efeito, as entidades administrativas dos Estados Nacionais responsáveis pela concessão do direito de patente, já há algum tempo, vêm permitindo tal nebulosidade nas interpretações referentes a essa categoria.

Exemplo desse embaralhamento são as disposições da Diretiva n. ${ }^{\circ}$ 98/44/CE, que apresenta três fontes de matéria biológica: a matéria biológica preexistente em seu estado natural; a matéria biológica isolada do seu estado natural; e a matéria biológica produzida com base num processo técnico. Tal Diretiva, em seu art. $3^{a}$, n. $^{\circ} 2$, e art. $5^{\circ}$, n. ${ }^{\circ} 1$ e 2 , dispõe que os produtos biológicos, ainda que preexistam e sejam idênticos em estado natural, podem ser patenteados, desde que isolados de seu ambiente natural ou produzidos por um processo técnico. ${ }^{5}$

Isso permite que, por detrás de um direito complexo como o de patentes, somado a complexidade da matéria sob a qual se faz a apreciação sobre sua inventividade ou novidade, as decisões administrativas e judiciais, assim como a linha que começa a ser seguida pela doutrina, tenham serventia somente para "alimentar o apetite desmedido da indústria alicerçada na apropriação da informação genética (a indústria genômica)". 6

5 MARQUES, J. P. Remédio. Patentes de Genes Humanos? Coimbra: Coimbra, 2001. p.24-25.

6 BERGEL, S. D. A Situação Limite do Sistema de Patentes: em Defesa da Dignidade das Invenções Humanas no Campo da Biotecnologia. In: CARNEIRO, F.; EMERICK, M. C. Limites: A Ética e o Debate Jurídico Sobre o Acesso e Uso do Genoma Humano. Rio de Janeiro: Fiocruz, 2000. p.191. 
Essa antecipação da patente, dito de outra forma, a concessão da patente para descobertas que não resultam de nenhuma atividade inventiva, ou ainda, a proteção de informações que ainda não resultaram em uma invenção de fato, têm razões, de certa forma, possíveis de definir e acarretam uma série de conseqüências que podem ser nocivas, inclusive para o próprio sistema de patentes.

Uma das possíveis razões dessa corrida contra o tempo pode ser sustentada pelo potencial econômico, que representa a informação sobre recursos genéticos e proporciona uma vantagem concorrencial para aquele que a detiver.

O que importa para a associação feita entre tecnociência e capital é informação que pode ser o diferencial no mercado. Os organismos e os indivíduos podem ser materialmente descartados a partir do momento em que seus componentes virtuais são apropriados. A informação passa a ser o diferencial. Nas palavras de Gregory Bateson, a informação é "a diferença que faz a diferença". 7

Essas rupturas conceituais se deram relativamente aos aspectos da natureza. No princípio foram os vegetais, com a Plant Act de 1930 nos Estados Unidos, que serviram de ponte entre a apropriação do inanimado para o vivo, e muito mais do que isso, serviram para superar essa distinção. Daí em diante, a separação entre o apropriável e o

7 SANTOS, L. G. dos. Invenção, Descoberta e Dignidade Humana. In: CARNEIRO, F.; EMERICK, M. C. Limites: A Ética e o Debate Jurídico Sobre o Acesso e Uso do Genoma Humano. Rio de Janeiro: Fiocruz, 2000. p.55-56. não apropriável passou a ser feita entre o natural-natural e o natural-artificial. Nessa cadeia da vida, o próximo passo no processo da apropriação dá-se pela concessão de exclusividade sobre patentes de invenções relacionadas a microorganismos transgênicos, como a bactéria chacrabarty, e, mais tarde, pelo patenteamento de animais superiores transgênicos, como o rato de Harvard.

A última fronteira, já superada, é apropriação, por meio de patentes, de invenção de elementos genéticos do corpo humano. Isso provoca uma reificação e mercantilização de todas as formas de vida. É a recombinação da vida para satisfação do mercado.

Nesse caminho, dois aspectos referentes ao humano serão analisados: a apropriação da biodiversidade como informação, por meio da aquisição do conhecimento tradicional dos povos a ela associada, e a apropriação de elementos informacionais do próprio humano.

\section{A BIODIVERSIDADE - DA MADEIRA À INFORMAÇÃO}

As florestas tropicais concentram grande parte da diversidade biológica do planeta e, junto delas, o conhecimento e a vida de muitos povos. Por séculos, essas culturas se reproduzem estabelecendo uma relação complexa com a natureza, que abarca saberes representados na sua produção material e expressão espiritual.

Essa diversidade e esses saberes a ela associados colocam a natureza e o conhecimento na mira das empresas de biotecnologia, 
devido ao potencial informacional que apresentam e pela vantagem concorrencial que pode resultar de um possível acesso a esse saber.

Porém, esse interesse é relativamente novo. Em um primeiro momento, que vai dos descobrimentos até a década de 1970, a exploração da natureza era fundada sobre um determinado modo extremamente predatório de conceber a floresta, que destruía a diversidade e negava a saberes locais qualquer valor. A exploração da natureza, feita por esse paradigma de percepção, é denominada por Vandana Shiva de "silvicultura científica". Ela assim a explica:

A silvicultura científica foi a falsa universalização de uma tradição local de exploração dos recursos florestais que nasceu dos interesses comerciais limitados que viam a floresta somente em termos de madeira com valor comercial. Primeiro reduziu o valor da diversidade da vida das florestas ao valor de umas poucas espécies que têm valor comercial e depois reduziu o valor dessas espécies ao valor de seu produto morto - a madeira. ${ }^{8}$

Nesse paradigma, a riqueza e a complexidade das florestas são reduzidas de duas formas: primeiro, ao se limitar o valor das florestas ao valor de mercado, ignorando a existência de pessoas que retiram dali seus alimentos; segundo, ao se aplicar o modelo da normalização, própria da sociedade disciplinar capitalista ocidental dos últimos séculos. Em resumo: é a implantação do modelo da fábrica à floresta.

A floresta natural é considerada, nessa perspectiva, anormal - caos - e deve ser

8 SHIVA, V. Monoculturas da Mente: perspectivas da biodiversidade e da biotecnologia. São Paulo: Gaia, 2003. p.32. substituída pela floresta fabricada - a disciplina, a ordem. A diversidade, a anormalidade, o caos devem ser eliminados como ervas daninhas e substituídos apenas por aquilo que é útil. E o que é útil, ou não, é determinado de forma unilateral pelo mercado. Assim, boa parte das áreas de florestas, como exemplo as do Estado do Paraná, foram substituídas pela monocultura agrícola ou pela monocultura silvícola.

Outro problema que acarreta essa forma de pensar e explorar a floresta, além de destruir o ecossistema, é que ela destrói também o modo de vida e a própria vida dos povos que por muitas gerações mantêm uma produção econômica, social e cultural retirada da natureza, sem a destruição da diversidade biológica e sem a redução da floresta ao aproveitamento econômico. A agricultura e a silvicultura para esses povos estão entrelaçadas e complementam-se na produção da vida: seus sistemas alimentares são baseados nessa necessária multiplicidade de espécies e de aproveitamentos.

Assim, junto com a destruição da natureza caminha a destruição dos povos e dos saberes. Nas palavras de Vandana Shiva:

Os povos tropicais também se tornam um lixo histórico descartável. Em lugar do pluralismo cultural e biológico, a fábrica produz monoculturas sem sustentabilidade na natureza e na sociedade. Não há lugar para o pequeno; o insignificante não tem valor. A diversidade orgânica é substituída pelo atomismo e pela uniformidade fragmentada. A diversidade tem de ser erradicada como uma erva-daninha, e as monoculturas uniformes - de plantas e pessoas - têm de ser administradas de fora porque não são mais auto-reguladas e autogeridas. Aqueles que não se ajustam à uniformidade são declarados incompetentes. A simbiose cede lugar à competição, à 
dominação e à condição de descartável. Não há sobrevivência possível para a floresta ou seu povo quando eles se transformam em insumo para a indústria. A sobrevivência das florestas tropicais depende da sobrevivência de sociedades humanas cujo modelo são os princípios da floresta. ${ }^{9}$

Em relação aos saberes, cabe ainda ressaltar, existe um desprezo histórico por qualquer forma de conhecimento que não o saber científico moderno. Os diversos sistemas de saberes tradicionais - os quais se transformaram de geração em geração com os diversos usos da floresta como fonte de alimento e auxiliar da agricultura, constituindo, por vezes, modos culturais, ora profanos, ora sagrados - foram eclipsados com a introdução dessa silvicultura científica, que trata a floresta apenas como fonte de madeira industrial e comercial. Os sabres locais foram considerados não-saber, misticismo ou conhecimento primitivo.

Impõe-se uma única e indiscutível verdade. Como um deus todo poderoso, a ciência não admite contestação:

Nem Deus, nem a tradição são privilegiados com a mesma credibilidade de que desfruta a racionalidade científica das culturas modernas... O projeto que a sacralidade da ciência transformou em tabu é o exame da ciência exatamente da mesma forma que qualquer outra instituição ou conjunto de práticas sociais. ${ }^{10}$

A partir dos anos 80 um novo paradigma de pensamento e de exploração é imposto sobre a floresta. Não são mais a madeira e a monocultura agrícola os principais elementos que irão atacar a diversidade. Agora, é a busca das informações genéticas oferecidas pela biodiversidade da floresta que atrai esses novos bandeirantes. Não mais o machado, nem o fogo, mas microscópios e computadores constituem as novas armas desse outro modelo que poderíamos chamar de modelo da floresta informação.

O valor econômico da natureza material é convertido em valor econômico artificial imaterial pela biotecnologia, como escreve Laymert Garcia dos Santos: "A Biotecnologia vem sendo um modo especial de destacar a biodiversidade dela mesma e transformá-la em 'capital artificial'!". 11

Agora não são mais necessários o desmatamento e a destruição para retirar dinheiro da floresta, ao contrário, é imprescindível manter a biodiversidade, pelo menos até recolher as informaçõeś necessárias.

A partir desse novo mercado, criado pela biotecnologia, as empresas da área se atiram aos países ricos em biodiversidade atrás de possíveis novos dados informacionais a serem retirados de elementos vivos. Nesse momento, os saberes locais, até então desprezados, passam a ser procurados e ganham novos contornos a partir momento em que o mercado lhe atribui importância. Evidentemente não se tornam saberes considerados científicos, não adquirem status de ciência, mas apresentam-se como atalhos para a tecnociência.

Os povos que vivem dessa biodiversidade apreenderam durante várias gerações a retirar aquilo que precisam para sua alimentação, para sua utilização doméstica e para a sua saúde. Esse conhecimento é o atalho que a indústria precisa para economizar tempo

\footnotetext{
9 SHIVA, V. Monoculturas ... p.33.

${ }^{10}$ SHIVA, V. Monoculturas ... p.24.
}

11 SANTOS, L. G. dos. Politizar as novas ... p.25. 
e dinheiro para as pesquisas que lhe permitem encontrar e conseguir dar utilidade específica à informação contida nos elementos biológicos disponíveis na natureza. Estima-se que as indústrias de biotecnologia chegam a economizar até $400 \%$ em tempo de pesquisa quando apoiadas em conhecimentos tradicionais. $^{12}$

O problema nessa relação é a forma de acesso a esse conhecimento, pois a regulação jurídica do acesso ao conhecimento tradicional tenta trabalhar com elementos que estão fora dos pressupostos lógicos do Direito moderno. A lógica proprietária, individualista e profana, não consegue compreender uma forma de vida não proprietária, coletiva e com elementos de sacralidade. Porém, o paradoxo reside no fato de que sem essa proteção resta aos povos o conflito direto com o mercado. Esse conflito é descrito por Andressa Caldas:

Por um lado a adoção de instrumentos legais próprios do sistema jurídico ocidental enseja uma imposição arbitrária de categorias e princípios estranhos aos variados modos de organização próprios das comunidades tradicionais. Por outro, a recusa da adoção desses instrumentos legais pode implicar na total liberalização da biopirataria, na medida em que se retira da esfera estatal a possibilidade de fiscalização do acesso aos recursos naturais que integram a biodiversidade. ${ }^{13}$

12 LIMA, A. Pode o sistema de patentes afetar a inalienabilidade dos saberes dos povos indígenas $\mathrm{e}$ populações tradicionais? In: Estado do São Paulo. Disponível em: www.isa.org.br/artigos/direito ao conhecimento. Acesso em 24/02/2005.

13 CALDAS, A. Regulação Jurídica do Conhecimento Tradicional: A Conquista dos Saberes. Curitiba, 2001, 188 f., Dissertação (Mestrado em Direito), Setor de Ciências Jurídicas, Universidade Federal do Paraná. p. 106.

\section{A NATUREZA HUMANA - DA AUTONOMIA À SUJEIÇÃO}

Assim como a natureza e o conhecimento, o homem também passa a interessar a esse biomercado. Em 1974, quando John Moore, um empresário do Alasca, sujeitava-se a um tratamento de leucemia no centro médico da Universidade da Califórnia, sua equipe médica descobriu que "o tecido do baço de Moore produzia uma proteína sangüínea que facilitava o crescimento de leucócitos, importantes agentes anticancerígenos". ${ }^{14}$ Sem o conhecimento e o consentimento do paciente, suas substâncias foram pesquisadas e, em 20 de março de 1984, ${ }^{15}$ uma linhagem celular, a partir daquele tecido, foi patenteada.

John Moore reivindicou a propriedade sobre os produtos lançados no comércio a partir de sua linhagem celular. Em 1990, a Suprema Corte do Estado da Califórnia decidiu contra ele, alegando que Moore não poderia ter propriedade sobre seu próprio corpo, pois o corpo humano não pode ser negociado como mercadoria.

A decisão do caso Moore é significativa, pois adota, contraditoriamente, a posição de que o corpo humano é distinto e externo ao sujeito. O corpo humano não pode ser comercializado, mas aceitou-se a utilização de elementos do corpo humano por terceiros como meio de produção com aplicação da técnica. Por outro lado, essa decisão valorizou o investimento que o laboratório realizou para a elaboração do produto final. Assim, o que determina a propriedade de

${ }^{14}$ RIFKIN, J. O Século da Biotecnologia: A Valorização dos Genes e a Reconstrução do Mundo. São Paulo: Makron Books, 1999. p.64.'

15 EDELMAN, B. La Personne en Danger. Paris: PUF, 1999. p. 290. 
produtos diretos ou indiretos do corpo humano é a valorização econômica dada pelo trabalho do biotecnólogo e não a origem dele. Essa decisão abriu o caminho para a apropriação, pelo instrumento da propriedade intelectual, de elementos do corpo humano, entre eles os genes. ${ }^{16}$

Existe, assim, um descompasso entre proteção jurídica do corpo humano e a experimentação científica, e os avanços da ciência e do mercado. ${ }^{17}$ Desse modo, existe um vínculo pessoal do sujeito com seu corpo sem valorização patrimonial e uma relação patrimonial no acréscimo de trabalho técnico sobre esse material.

Adotando a concepção de que o corpo humano não pode ser objeto de comércio, a Constituição da República Federativa do Brasil, art. 199, § 4. ${ }^{\circ}$, dispõe sobre o princípio da gratuidade: "a lei disporá sobre as condições e os requisitos que facilitem a remoção de órgãos, tecidos e substâncias humanas para fins de transplantes, pesquisa e tratamento, bem como a coleta, processamento e transfusão de sangue e seus derivados, sendo vedado todo o tipo de comercialização".

O princípio da gratuidade, que impede a cessão ou transmissão onerosa de elementos do corpo humano, ganha contornos específicos com a Declaração Universal do Genoma Humano e dos Direitos Humanos, que, em seu artigo $4 .^{\circ}$, determina que, em seu estado

16 Conforme aponta Salvador Bergel, entre 1981 y 1985 foram concedidos 1.175 patentes para seqüencias de DNA humano em todo o mundo. (BERGEL, S. D. Patentamiento de genes y secuencias de gens. In: Revista Derecho e Genoma Humano, 8/ 1998, p.32.).

17 GEDIEL, J. A. P. Os Transplantes de Órgãos e a Invenção Moderna do Corpo. Curitiba: Moinho do Verbo, 2000. p. 105. natural, o genoma humano não deve dar lugar a ganhos financeiros. Esse princípio admite a autonomia do sujeito para tomar decisões sobre seu corpo, mas permite somente as disposições corporais orientadas pelo sentido de solidariedade social. ${ }^{18}$

No quadro jurídico do direito subjetivo, para possibilitar o acesso a esses recursos genéticos, é utilizado o consentimento informado, o que pressupõe o gozo pleno da autonomia privada, e que o doador tenha conhecimento dos riscos e potencialidades da pesquisa.

Essa situação remete-nos a um problema: ao fato de que, no Brasil, as situações socioeconômicas e a pluralidade cultural são barreiras para a autonomia da vontade e o livre consentimento, como aponta o Professor Carlos Frederico Marés de Souza Filho:

Entretanto, se formos ao sumo do direito, é essa vontade que tem de ser discutida e problematizada, porque toda questão ética resulta na manifestação e em como se manifesta essa vontade [, pois] há vícios de vontade muito mais sérios que não contam quando se vende um bem, quando se transfere um bem, mas se conta em profundidade quando se atinge o interior da pessoa. É claro que a necessidade econômica não é vício de vontade para vender um carro, mas é vício de vontade profundo e intransponível para se permitir uma pesquisa de genes. ${ }^{19}$

18 GEDIEL, J. A. P. Tecnociência, Dissociação e Patrimonizalização Jurídica do Corpo Humano. In: FACHIN, L. E. (Coord.). Repensando Fundamentos do Direito Civil Brasileiro Contemporâneo. Rio de Janeiro: Renovar, 1998. p.71.

19 SOUZA FILHO, C. F. M. de. Arcabouço Jurídico e as Pesquisas de Manipulação da Genética Humana. In: CARNEIRO, F.; EMERICK, M. C. Recursos Genéticos Humanos: Limites ao Acesso Debate Interdisciplinar Sobre a Regulamentação do Acesso e do Uso do Genoma Humano no Brasil. Rio de Janeiro: Fiocruz, 1997. p.40-41. 
E esta situação agrava-se quando o consentimento deve ser obtido não de indivíduos, mas de grupos culturalmente diferenciados, como ocorre com as populações indígenas. $^{20}$

Além disso, a própria complexidade do ser humano e de seu genoma humano acrescentam mais um limite para o consentimento para sua utilização, comercial ou não, uma vez que o genoma é um patrimônio, ao mesmo tempo, universal, pessoal e comunitário. Conforme Bartha Knoppers:

Le projet international de cartographie et de séquençage du genome humain démontrera que le patrimoine génétique est à la fois universel, personnel et communautaire. Universel parce qu'il changera irrémédiablement les coordennées anthropologiques de l'espèce humaine. Personnel puisqu'il changera notre compréhension de la causalité et de la pathogenèse des maladies. Communautaire parce qu'il révélera aussi et de la solidaridarité biologique entre les personnes dans une societé donnée. ${ }^{21}$

20 "Para muitas dessas populações a perenização significa que o espírito não tem mais sossego, nunca mais. Para essas populações a morte tem todo um processo completamente diferente do nosso". SANTOS, L. G. dos. Sobre a Questão Indígena (debate). In: CARNEIRO, F.; EMERICK, M. C. Recursos Genéticos Humanos: Limites ao Acesso Debate Interdisciplinar Sobre a Regulamentação do Acesso e do Uso do Genoma Humano no Brasil. Rio de Janeiro: Fiocruz, 1997. p.91.

21 KNOPPERS. B. M. Le Genome Humain: Um Patrimoine Universel, Personel et Communautaire. In: MÉLANÇON. M. J.; LAMBERT. R. D. (Dir.). Le Genome Humain: Une Responsabilité Scientifique et Sociale. Actes d'un colloque tenu dans le cadre du Congrès de l'ACFAS, à l'Université de Sherbrooke, le 22 mai 1991, p. 101. Tradução livre: O projeto internacional de cartografia e de seqüenciamento do genoma humano demonstrará que o patrimônio genético é ao mesmo tempo universal, pessoal e comunitário.
O Brasil, acompanhando as preocupações da Declaração Universal do Genoma Humano e dos Direitos Humanos, adotada pela UNESCO, em 1997, em sua 29. ${ }^{a}$ sessão de Conferência Geral, vem elaborando instrumentos normativos ${ }^{22}$ para regular o acesso e o uso de informações genéticas de modo a diminuir o impacto da biotecnologia sobre o homem e o hiato entre a Tecnociência e o Direito. ${ }^{23}$

Os principais instrumentos legais, já em vigor, são: i) a Lei n. ${ }^{\circ} 11.105$, de março de 2005, que estabelece normas para os usos das técnicas de engenharia genética, proíbe, no art. $6^{\circ}$, no inciso I, II e III, engenharia genética em organismo vivo ou o manejo in vitro de ADN/ARN natural ou recombinante, a engenharia genética em célula germinal humana, zigoto humano e embrião, e a clonagem humana; ii) a Resolução n. ${ }^{\circ} 347$, do Conselho Nacional de Saúde, de 13 de janeiro de 2005, que visa regulamentar o armazenamento e a utilização de material biológico humano no âmbito de projetos de

Universal porque ele mudará irremediavelmente as coordenadas antropológicas da espécie humana. Pessoal porque mudará nossa compreensão da causa e da patogênese das doenças. Comunitário porque ele revelará também a solidariedade biológica entre as pessoas de uma sociedade dada.

22 A Constituição Federal de 1988 é o principal instrumento normativo da matéria, na medida em que considera a dignidade da pessoa humana como um dos fundamentos do Estado, protegendo-a com grande rol de direitos discriminados no art. 5. ${ }^{\circ}$; prevê um capítulo especial para tratar do meio ambiente, o qual considera bem de uso comum do povo; e destina outro para tratar dos índios, reconhecendo sua organização social, cośtumes, língua, crenças e tradições.

23 GEDIEL, J. A. P. Tecnociência, Dissociação... p. $58-59$ 
pesquisa. A Lei n. ${ }^{\circ} 9.279$, de 14 de maio de 1996, que trata da proteção da propriedade industrial e que, no artigo 18, prevê uma proibição genérica para a apropriação, por patentes, de elementos genéticos humanos.

Essa proibição legal genérica, que em primeira análise apresenta-se como uma norma protetora do homem e de seus elementos biológicos da utilização, como objeto, com fins lucrativos privados, nas relações jurídicas, poderá tornar-se, da mesma forma que acontece com os vegetais e animais, simplesmente uma omissão legal que deixará para o mercado regular a matéria, desprotegendo, assim, o corpo humano da mercantilização.

Todavia, ocorre que não existe esta mesma vedação para o outro lado do processo, que é a apropriação pelo incremento da intervenção humana e comercialização dos produtos finais e decorrentes destes materiais.

O sistema jurídico de patentes, conforme visto, tornou-se o instrumento privilegiado para articular e sustentar a rèlação entre a tecnociência e o mercado. É a ferramenta que permite ou nega o acesso para a concessão dos possíveis benefícios da apropriação e da utilização dos produtos decorrentes dessa nova era pós-industrial.

$\mathrm{O}$ homem, por esse processo, passa a ser objeto das relações comerciais e jurídicas, não mais como escravo, mas como informação suscetível de valorização patrimonial.

O ser humano participa desse sistema por duas formas de inclusão: ou é consumidor, se tiver condições para tal, ou é fornecedor de matéria-prima. Em nenhuma hipótese ele é colocado como sujeito desse processo.

Se, por um lado, os incluídos são limitados ao consumo, sua condição de cidadão é substituída por sua condição de consumidor, "o que sobrou foi o direito de consumir, não o direito do consumidor". ${ }^{24}$ Por outro lado, os descartáveis são proibidos de terem acesso aos benefícios da biotecnologia por não arcarem com os custos da propriedade intelectual. E todos são matérias-primas em potencial.

\section{OS LIMITES DO SISTEMA DE PATENTES}

O sistema econômico, cultural e político, que sustenta o sistema jurídico de proteção às invenções industriais, elege suas verdades determinando, arbitrariamente, os bens e os sujeitos que estão dentro das normas para usufruírem os benefícios trazidos. O mesmo pode ser constatado em relação às inovações tecnológicas e sua proteção patentária, que não se preocupa com "a vida concreta de cada sujeito humano" do seu referencial de valores de ser e dever-ser. ${ }^{25}$

Partindo de uma análise crítica desse sistema podemos observar que ele produz opressão, porque nega os benefícios para aqueles que já estão dentro do sistema e os transforma em vítimas. E exclusão, porque não consegue conviver com aqueles que estão fora do sistema sem colonizá-los. Podemos dizer que temos uma opressão que exclui e uma exclusão que coloniza.

Recentemente, uma querela internacional colocou às vistas da opinião pública o

${ }^{24}$ SANTOS. L. G. dos. Politizar as novas ... p. 127.

25 DUSSEL, E. Ética da libertação: na idade da Globalização e da Exclusão - na Idade da Globalização e da Exclusão. Petrópolis: Vozes, 2000. p. 14 . 
problema da exclusão causada pela propriedade intelectual. Em 2000, a África do Sul decidiu importar da Índia e do Brasil medicamentos genéricos para o tratamento da Aids, tendo em vista que 1 em cada 5 adultos sul-africanos são portadores do vírus HIV, o que representa, aproximadamente, 4,2 milhões de pessoas, e que mais de 17 milhões já morrem por causa da Aids, ${ }^{26}$ acrescido do fato de a condição econômica da população e os preços dos remédios protegidos por patentes não permitirem o acesso da maioria aos medicamentos. ${ }^{27}$

Em reação a essa atitude, quarenta e duas empresas farmacêuticas transnacionais organizaram uma campanha contra aquele país, argumentando que sua posição violava os direitos de patentes. Os Estados Unidos da América ameaçaram a África do Sul com sanções comerciais. ${ }^{28}$

Ao comentar a ação proposta contra a produção e a importação de genéricos contra a Aids, o presidente da Associação das Indústrias Farmacêuticas da África do Sul faz a seguinte afirmação: “O caso tem pouco a

26 PIOVESAN, F. Vida Acima dos Lucros. Folha de São Paulo, 28/03/2001, Caderno Opinião, p.A3.

27 "Aunque este fue uno de los casos más conocidos, no fue el primero ni el único. En 1993, Estados Unidos presionó a Tailandia hasta que aprobó una ley prohibiendo las importaciones paralelas. En 1998, Tailandia intentó producir un medicamento genérico para el SIDA, patentado por Bristol Myers Squibb. Estados Unidos amenazó con boicotear varios productos clave de explotación tailandeses. En el 2000, le obligó a aprobar una ley que restringe severamente las licencias obligatorias. (RIBEIRO, S. Trasnacionales Farmacéuticas Contra la Salud. La insignia, 7/7/2002, Disponible en: <www.lainsignia.org/2002/julio/cyt_003.htm> acesso en: 18.07.2002)

${ }^{28}$ RIBEIRO, S. Trasnacionales ... ver com a Aids. Isso é uma luta sobre a extensão de poder e sobre uma lei que ainda não sabemos o que significa". Flávia Piovesan compara essa declaração com as declarações analisadas por Hannah Arendt, de Adolf Eichmann, em Israel, quando do seu julgamento, acusado de transportar milhões de judeus aos campos de extermínio nazistas, mostrando absoluta frieza e ausência de ódio ao traduzir o rigor burocrático com que desempenhava as suas funções, "cumprindo ordens". É a "banalidade do mau". 29

Não é de assustar-se com essas declarações, uma vez que o acordo, ADPIC/TRIPS, projetado para criar uma estrutura uniforme de proteção à propriedade, foi arquitetado em grande parte por uma colisão de 12 empresas que se autodenominavam Comitê de Propriedade Intelectual (IPC). ${ }^{30}$ Entre elas estavam as grandes empresas no campo da biotecnologia, como a Johnson \& Johnson, Bristol Myers, Merck, Pfizer, Monsanto e Du Pont. James Enyart, da Monsanto, explica a base racional estratégica desse comitê:

uma vez que nenhum grupo comercial existente se encaixava de fato no projeto de lei, tivemos que criar um. [...] Uma vez criado, a primeira tarefa do IPC foi repetir o trabalho missionário que realizamos nos Estados Unidos nos velhos tempos, desta vez com as associações industriais da Europa e do Japão, para convencê-los de que um código era possível. [...] Consultamos muitos grupos de interesse durante todo o processo. Não foi uma tarefa fácil, mas nosso Grupo Trilateral foi capaz de deduzir das leis dos países mais avançados os princípios

\footnotetext{
29 PIOVESAN, F. Vida Ácima ...

${ }^{30}$ RIFKIN, J. O Século..., p.54; SHIVA, V. Biopirataria: A Pilhagem da Natureza e do Conhecimento. Petrópolis, RJ: Vozes, 2001. p.108.
} 
fundamentais para a proteção de todas as formas de propriedade intelectual. [...] Além de vender nossos conceitos em casa, fomos até Genebra, onde apresentamos nosso documento aos membros da Secretaria do GATT. Também aproveitamos a oportunidade para apresentá-lo a representantes de muitos países em Genebra. [...] O que descrevi a vocês absolutamente não tem precedentes no GATT. A indústria identificou um grande problema no comércio internacional. Elaborou uma solução, tornou-a uma proposta concreta e vendeu-a ao nosso e a outros governos. [...] As indústrias e operadores do mundo comercial desempenharam, simultaneamente, os papéis de paciente, diagnosticador e terapeuta. ${ }^{31}$

\section{As grandes indústrias conseguiram} estabelecer, mediante a OMC, a obrigação de os países elaborarem legislações que não apenas favorecem seus interesses, em detrimento de quaisquer outros interesses nacionais ou humanitários, mas também não contentes com essas conquistas, em meados dos anos noventa, elaboraram uma lista com aqueles países que consideravam ter proteção jurídica às patentes inadequadas. Devido à pressão da opinião pública, houve um recuo das empresas no caso da Aids. Apesar disso, as empresas continuam trabalhando para endurecer a proteção da propriedade das patentes:

En la más reciente reunión ministerial de la OMC, en Doha en el 2001, estos ejemplos, por su inhumanidad, obligaron a que la OMC declarara que mantendría los mecanismos para acceder a medicinas más baratas. Pero ya en una reciente reunión de la OMC en Ginebra (25-27 de junio de 2002), Estados Unidos plantéo que el uso de estas medidas sea solamente como excepción. Las multinacionales farmacéuticas siguen trabajando para endurecer los ADPIC, extendiendo aún más sus monopolios e incluyendo también las patentes

${ }^{31}$ Apud. SHIVA, V. Biopirataria ..., p.109 de plantas y animales. Es uno de los temas clave de la próxima reunión ministerial de la OMC en Cancún en el 2003, y también de las negociaciones del ALCA. ${ }^{32}$

Interessante notar que a imposição do mercado é tão grande que, mesmo sendo admitida no sistema de patentes internacional a utilização do objeto da patente sem a autorização do titular, nos art. 30 e 31 do ADPIC, as empresas não permitem a utilização dessa exceção aos direitos conferidos. ${ }^{33}$

Sob um outro aspecto, esse sistema de propriedade sobre invenções determina as linhas de pesquisa, conforme o resultado mercadológico do seu produto, especializando o conhecimento no que tem retorno financeiro e deixando de lado outras especializações básicas de um sistema de conhecimento. É o que David Ehernfeld ironicamente chamou de "esquecimento", 34 do mesmo modo, na área da saúde, determinam quais enfermidades

32 RIBEIRO, S. Trasnacionales ...

33 "Sin embargo, tanto las licencias obligatorias que permiten que se obligue a los poseedores de una patente a licenciarla - como las importaciones paralelas - que permiten comprar un producto con patente válida en el país importador en otro país donde se vende más barato - están previstas en la OMC, por razones de salud pública y otras, "para promover el interés público en sectores de importancia vital'." (RIBEIRO, S. Trasnacionales ...)

34 Vandana Shiva traz o exemplo de David Ehrenfeld, que relata o fato de estar desaparecendo o número de pessoas treinadas em ecologia de minhocas. Embora as minhocas sejam essenciais para nossa sobrevivência, seu estudo definha por falta de investimento: "As minhocas, por exemplo, estão entre as espécies cruciais para nossa sobrevivência. A cultura depende da fertilidade do solo, e a fertilidade do solo depende enormemente das minhocas. Elas melhoram a fertilidade da terra depositando nela matéria fecal e aumentando sua permeabilidade ao ar e a água”. (SHIVA, V. Biopirataria ... p.38) 
merecem investimento para pesquisa, não por sua gravidade ou extensão de vítimas, mas pelas condições de consumo dos enfermos. ${ }^{35}$

No caso daqueles que não têm acesso aos medicamentos, como a exclusão pela definição das linhas de pesquisa, temos um tipo de opressão que exclui, opressão porque vitima pessoas que vivem dentro de um paradigma moderno; exclui, porque não permite o acesso aos benefícios da modernidade.

Outra forma de opressão que excluiu é aquela que atinge determinados aspectos da vida de algumas pessoas que estão inseridas e conseguem se beneficiar, satisfatoriamente, de um sistema cultural e econômico que está por trás do sistema de patentes. Essa forma de opressão se deu, por exemplo, no caso John Moore, já analisado. Existem, também, circunstâncias em que o sistema exclui por um limite de sua própria racionalidade. Isso ocorre em duas situações: quando a criatividade não decorre do conhecimento admitido pela racionalidade moderna como conhecimento válido; e quando o produtor desse conhecimento não é um sujeito nem individualizável e não sequer pode ser definido no tempo e espaço da vida individual humana.

35 "Los soportes tecnológicos de la nueva economía, así como los avances científicos que mejoran y preservan nuestra salud y los inventos que hacen la vida más fácil, son fruto de la investigación. Y el coste de esta investigación es mucho menor que la plusvalía que generan y de la que no siempre se benefician directamente. Por eso, en el campo de la ciencia se favorecen unas líneas de investigación frente a otras, según los dividendos que van a producir, por más que sus beneficios sobre la salud estén fuera de toda duda." (DESOJO, Arancha. Tecnología Improductiva. La Insígnia 16/ 09/2001. <www.lainsignia.org/2001/septiembre/ cyt_007.htm> Acesso en: 18.07.2002)
A criatividade na produção de inventos suscetíveis de patenteamento decorre da construção conceitual de teorias e técnicas a partir de princípios epistemológicos e metodológicos da ciência moderna ocidental. A racionalidade científica moderna é totalitária, "na medida em que nega o caráter racional a todas as formas de conhecimento". 36

Assim, a criatividade eleita pelo sistema de patentes não considera outras formas de criatividade que, segundo Vandana Shiva, no caso das ciências da vida, devem incluir três níveis:

1. A criatividade inerente aos seres vivos, que lhes permitiu evoluir, recriar-se e regenerar-se. 2. A criatividade de comunidades indígenas que desenvolveram sistemas de conhecimento para conservar e utilizar a rica diversidade biológica do nosso planeta.

3. A criatividade dos cientistas modernos nos laboratórios de universidade ou grandes empresas, que descobrem maneiras de usar os seres vivos para gerar lucro. ${ }^{37}$

A proteção do sistema internacional de patentes se dá apenas no terceiro nível. Cabendo ressaltar que mesmo a criatividade dentro de uma racionalidade científica moderna não é reconhecida se não interessa a sua aplicação industrial.

Os conhecimentos e a tecnologia existentes fora dos padrões modernos são ignorados. Assim, permite-se a apropriação, como bens jurídicos e de mercado, de quaisquer seres vivos, independentemente das comunidades terem trabalhado em sua domesticação e transformação por diversas gerações. As criações de comunidades de variedades

${ }^{36}$ SANTOS, B. de S. A Crítica da Razão Indolente: Contra o Desperdício da Experiência. São Paulo: Cortez, 2000. p.61.

${ }^{37}$ SHIVA, V. Biopirataria ... p.30-31. 
de plantas e seu uso determinado pelo conhecimento tradicional é apropriada com terra nullius.

Muito embora a tecnologia autóctone não seja reconhecida, importa destacar que a biodiversidade não é silvestre. Há milhares de anos, de geração em geração, os povos indígenas e as comunidade locais têm desenvolvido uma tecnologia própria, que produz inovações que se têm acumulado através do tempo, cujo registro é a sua própria existência. Estas inovações são desconsideradas pelo mundo ocidental, que não admite que povos indígenas sejam capazes de investigar, desenvolver e criar inovações. ${ }^{38}$

O que está fundamentando a criatividade patenteável é agregação de valor, e o único valor reconhecido é o que decorre da associação do trabalho ao capital. "O processo do trabalho científico, além de transformar o estado natural, promove uma desmaterialização da coisa, agrega-lhe um grande valor de mercado e, por isso, o Direito realiza tal distinção de modo que possa figurar como objeto de relações jurídicas". 39

O sistema internacional de patentes encontra seu limite, também, na racionalidade do Direito que consegue somente trabalhar com sujeitos de direito individuais ou individualizáveis e com bens suscetíveis de titularidade exclusiva. Na eloqüente crítica de Carlos Marés: "Assim, cada vez que se

${ }^{38}$ CALDAS, A. Ob. cit. p.87-88.

${ }^{39}$ GEDIEL. J. A. P. Declaração universal do Genoma Humano e Direitos Humanos: Revisitação Crítica dos Instrumentos Jurídicos. In: CARNEIRO, F.; EMERICK, M. C. Limites: A Ética e o Debate Jurídico Sobre o Acesso e Uso do Genoma Humano. Rio de Janeiro: Fiocruz, 2000. p.163. No mesmo sentido SHIVA, V. Biopirataria ... p.98. fala em direito, há que se buscar, para a lógica do sistema, um titular, uma pessoa um sujeito de direitos, individual, ainda que seja uma ficção. De outro lado, é necessário que se tenha um bem, uma coisa, um objeto que componha este patrimônio individual". ${ }^{40}$

Quando se depara com situações em que os sujeitos não podem ser individualizáveis e os bens não têm um único titular, como no caso das comunidades tradicionais e seu conhecimento coletivo, o sistema de patentes encontra seu limite. A alternativa para fugir à apropriação desse conhecimento, mesmo que de forma inadequada, é a inclusão do conhecimento coletivo como um bem com valor econômico e do reconhecimento das comunidades como sujeitos coletivos.

O Acordo ADPIC/TRIPS preconiza, no art. 27, 3, que um sistema de patentes ou um sistema sui generis para a proteção dos recursos biológicos deve ser adotado pelos países que excluem a proteção patentária para animais ou plantas, para incluir a tutela destes no sistema internacional vigente. Diante disso, "muitas organizações de povos indígenas e outras comunidades locais, juntamente com organizações não-governamentais ligadas à proteção da diversidade biológica, estão buscando estabelecer um sistema legal que reconheça as inovações das comunidades tradicionais, mas que não seja excludente nem monopólico". 41

${ }^{40}$ SOUZA FILHO, C. F. M. de. Os Direitos Invisíveis. In: OLIVEIRA, F. de e PAOLI, M. C. (Org.) Os Sentidos da Democracia: Políticas do Dissenso e Hegemonia Global. Petrópolis, RJ: Vozes, 1999. p.311.

41 CALDAS. A. Ob. cit. p.119. 
Nessa busca, foi forjada a noção de Direitos Intelectuais Coletivos, ${ }^{42}$ proposta lançada pela Rede do Terceiro Mundo (Third World Network), com vistas a proteger os conhecimentos e inovações que não se adaptam ao sistema de propriedade intelectual.

Nessa laboração, em que tiveram papel destacado Vandana Shiva, da Índia, Tewolde Egziabher, da Etiópia, e Gurdial Nijar, da Malásia, propõe-se que os países do Sul deveriam tomar a iniciativa de defender sua riqueza biológica e o conhecimento tradicional, regulando as condições de acesso aos recursos biológicos, que se encontram intrinsecamente ligados.

Essa formulação pretende estabelecer uma proteção às comunidades tradicionais e seus conhecimentos sobre a utilização dos recursos naturais, evitando, assim, a biopirataria, que permite a apropriação desses elementos sem o devido retorno para as comunidades. Contudo, mesmo essa proposta, que busca preservar as comunidades e a biodiversidade, também não consegue escapar da colonização da vida e do conhecimento pelo sistema de mercado.

Conclui-se que, no percurso das transformações do sistema de patentes, a vida humana e o conhecimento dos povos são reduzidos à informação e sujeitados à lógica de mercado. A razão moderna e profana impõe-se sobre os saberes permeados pelo sagrado, a natureza transforma-se em naturezaartificial, e o humano, em mercadoria.

42 SANTOS. L. G. Gestión de la Bioidiversidad y protección del Conocimiento Colectivo: Opciones de Política Existentes y Viables para los Países Andinos y Amazônicos. Primeiro Foro Internacional de los Paíse Andinos y Amazônicos sobre Biodiversidad. Modolo 2: Marco de Políticas.

\section{REFERÊNCIAS}

BERGEL, S. D. A Situação Limite do Sistema de Patentes: em Defesa da Dignidade das Invenções Humanas no Campo da Biotecnologia. In: CARNEIRO, F.; EMERICK, M. C. Limites: A Ética e o Debate Jurídico Sobre o Acesso e Uso do Genoma Humano. Rio de Janeiro: Fiocruz, 2000. p.185-208

BERGEL, S. D. Patentamiento de genes y secuencias de genes. In: Revista Derecho e Genoma Humano, 8/1998, p.31-59.

CALDAS, A. Regulação Jurídica do Conhecimento Tradicional: A Consquista dos Saberes. Curitiba, 2001, 188 f., Dissertação (Mestrado em Direito), Setor de Ciências Jurídicas, Universidade Federal do Paraná. DESOJO, A. Tecnología Improductiva. La Insignia 16/09/2001. <www.lainsignia.org/2001/ septiembre/cyt_007.htm> Acesso en: 18.07.2002.

DUSSEL, E. Ética Da Libertação: Na Idade da Globalização e da Exclusão. Petrópolis: Vozes, 2000.

EDELMAN, B. La Personne en Danger: Paris: PUF, 1999.

GEDIEL, J. A. P. Os Transplantes de Órgãos e a Invenção Moderna do Corpo. Curitiba: Moinho do Verbo, 2000.

GEDIEL, J. A. P. Tecnociência, Dissociação e Patrimonizalização Jurídica do Corpo Humano. In: FACHIN, L. E. (Coord.). Repensando Fundamentos do Direito Civil Brasileiro Contemporâneo. Rio de Janeiro: Renovar, 1998. p.57-86.

GEDIEL, J. A. P. Declaração universal do Genoma Humano e Direitos Humanos:

Revisitação Crítica dos Instrumentos Jurídicos. In: CARNEIRO, F.; EMERICK, M. C. Limites: A Ética e o Debate Jurídico Sobre o Acesso e Uso do Genoma Humano. Rio de Janeiro: Fiocruz, 2000. p.159-166. 
KNOPPERS. B. M. Le Genome Humain: Um Patrimoine Universel, Personel et Communautaire. In: MÉLANÇON. M. J.; LAMBERT. R. D. (Dir.). Le Genome Humain: Une Responsabilité Scientifique et Sociale. Actes d'un colloque tenu dans le cadre du Congrès de l'ACFAS, à l'Université de Sherbrooke, le 22 mai 1991, p.101-110.

LIMA, A. Pode o sistema de patentes afetar a inalienabilidade dos saberes dos povos indígenas e populações tradicionais? In: Estado do São Paulo. Disponível em <www.ida.org.br/artigos/ direito ao conhecimento > Acesso em: 24/02/05.

MARQUES, J. P. Remédio. Patentes de Genes Humanos? Coimbra: Coimbra, 2001.

PIOVESAN, F. Vida Acima dos Lucros. In: Folha de São Paulo, 28/03/2001, Caderno Opinião, p. A3.

RIBEIRO, S. Trasnacionales Farmacéuticas Contra la Salud. La insignia, 7/7/2002, Disponible em: <www.lainsignia.org/2002/julio/ cyt_003.htm> Acesso en: 18.07.2002.

RIFKIN, J. O Século da Biotecnologia: A Valorização dos Genes e a Reconstrução do Mundo. São Paulo: Makron Books, 1999.

SANTOS, B. de S. A Crítica da Razão Indolente: Contra o Desperdício da Experiência. São Paulo: Cortez, 2000.

SANTOS, L. G. dos. Informação, Recursos Genéticos e Conhecimento Tradicional Associado. In: AZEVEDO, C. M. do A.; FURRIELA, F. N. da. (Orgs.). Biodiversidade e Propriedade Intelectual. São Paulo: SMA, 2001. p.33-68.

SANTOS, L. G. dos. Invenção, Descoberta e Dignidade Humana. In: CARNEIRO, F; EMERICK, M. C. Limites: A Ética e o Debate Jurídico Sobre o Acesso e Uso do Genoma Humano. Rio de Janeiro: Fiocruz, 2000. p.55-64.
SANTOS, L. G. dos. Politizar as novas tecnologias: o Impacto sócio-técnico da informação digital e genética. São Paulo: Editora 34, 2003.

SANTOS, L. G. dos. Sobre a Questão Indígena (debate). In: CARNEIRO, F.; EMERICK, M. C. Recursos Genéticos Humanos: Limites ao Acesso-Debate Interdisciplinar Sobre a Regulamentação do Acesso e do Uso do Genoma Humano no Brasil. Rio de Janeiro: Fiocruz, 1997. p.93-97.

SANTOS, L. G. dos. Gestión de la Biodiversidad y protección del Conocimiento Colectivo: Opciones de Política Existentes y Viables para los Países Andinos y Amazônicos. Primeiro Foro Internacional de los Paíse Andinos y Amazônicos sobre Biodiversidad. Modolo 2: Marco de Políticas.

SHIVA, V. Biopirataria: A Pilhagem da Natureza e do Conhecimento. Petrópolis, RJ: Vozes, 2001.

SHIVA, V. Monoculturas da Mente: perspectivas da biodiversidade e da biotecnologia. São Paulo: Gaia, 2003.

SOUZA FILHO, C. F. M. de. Arcabouço Jurídico e as Pesquisas de Manipulação da Genética Humana. In: CARNEIRO, F.; EMERICK, M. C. Recursos Genéticos Humanos: Limites ao Acesso - Debate Interdisciplinar Sobre a Regulamentação do Acesso e do Uso do Genoma Humano no Brasil. Rio de Janeiro: Fiocruz, 1997, p.37-42.

SOUZA FILHO, C. F. M. de. Os Direitos Invisíveis. In: OLIVEIRA, F. de e PAOLI, M. C. (Org.) Os Sentidos da Democracia: Políticas do Dissenso e Hegemonia Global. Petrópolis, RJ: Vozes, 1999, p.307-334. 